\title{
On the use of biomass size spectra linear adjustments to design ecosystem indicators
}

\author{
PAÚL GÓMEZ-CANCHONG ${ }^{1,2}$, JOSÉ M. BLANCO ${ }^{3}$ and RENATO A. QUIÑONES ${ }^{1,2}$ \\ ${ }^{1}$ COPAS Sur-Austral, Centro de Investigación Oceanográfica en el Pacífico Sur-oriental, Universidad de Concepción, \\ Concepción, Chile. E-mail: paulgomez@udec.cl \\ ${ }^{2}$ Departamento de Oceanografía, Universidad de Concepción, P.O. Box 160-C, Concepción, Chile. \\ ${ }^{3}$ Grupo de Investigación en Ecología Marina y Limnología (GEML), Departamento de Ecología, Universidad de Málaga, \\ Facultad de Ciencias, 29071 Malaga, Spain.
}

\begin{abstract}
SUMMARY: Biomass size spectra describe the structure of aquatic communities ataxonomically. The slope $(b)$ of the normalized biomass size spectrum (NBSS) is often used as an indicator of the impact of perturbations, such as pollution or overfishing. The NBSS intercept $(a)$, has generally been ignored on the basis of a correlation between the NBSS slope and intercept, although this correlation has not been shown to be universal. We assessed whether the NBSS parameters are correlated using: (i) theoretical analysis, (ii) virtual communities randomly generated based only on statistical considerations, and (iii) virtual food webs changing over time following a dynamic bioenergetic model. We also analyzed whether the parameters of the Pareto distribution are correlated or not, using approaches (i) and (ii). We found that when communities change over time there is no single relationship between the two NBSS parameters, due to a dependence on the variation in total community abundance $(N)$. We conclude that to characterize any aquatic system at least two parameters are necessary from the NBSS triad $N, a, b$. In the case of the Pareto distribution, both $N_{\text {Pareto }}$ and $b_{\text {Pareto }}$ are necessary.
\end{abstract}

Keywords: biomass size spectrum, Pareto distribution, bioenergetic model, linear biomass hypothesis, complex food webs, ecosystem management.

RESUMEN: EL USO DEL AJUSTE LINEAL EN LOS ESPECTROS DE TAMAÑo DE BIOMASA PARA DISEÑAR INDICADORES ECOSISTÉmicos. - Los espectros de tamaño de biomasa son un método ataxonómico para describir la estructura de comunidades acuáticas. La pendiente $(b)$ del espectro de tamaños de biomasa normalizado (ETBN) se usa como un indicador del impacto de perturbaciones tales como polución y sobrepesca. El intercepto del ETBN $(a)$ ha sido normalmente ignorado debido a una correlación observada entre la pendiente y el intercepto del ETBN, aunque no se ha demostrado la recurrencia de esta correlación. Se evaluó esta correlación entre los parámetros usando: (i) análisis teórico, (ii) comunidades virtuales generadas aleatoriamente basado en consideraciones estadísticas, y (iii) redes tróficas virtuales cambiando en el tiempo siguiendo un modelo bioenergético dinámico. Además, se analizó si los parámetros de la distribución de Pareto estaban o no correlacionados usando los enfoques (i) y (ii). Cuando las comunidades cambian en el tiempo no existe una única correlación entre los parámetros del ETBN, debido a una dependencia en la variación de la abundancia comunitaria $(N)$. Para caracterizar cualquier sistema acuático se necesitan al menos dos coeficientes del ETBN de la triada $N, a, b$. En la distribución de Pareto los dos parámetros, $N_{\text {Pareto }}$ y $b_{\text {Pareto }}$, son necesarios.

Palabras clave: espectro de tamaños de biomasa, distribución de Pareto, modelo bioenergético, hipótesis de la biomasa constante, redes tróficas complejas, gestión del ecosistema.

\section{INTRODUCTION}

The size spectrum is a two-dimensional graphical representation of ecological pyramids (Cousins 1985) designed to show the biomass distribution across differ- ent size classes in a community. The size spectrum has been recommended as an alternative way to describe the structure of aquatic ecosystems (e.g. Rodriguez and Mullin 1986, Dickie et al. 1987, Gaedke 1993, Blanchard et al. 2009, Rochet and Benoit 2011). This 
TABLE 1. - List of the different size spectrum coefficients and different processes for which they have been proposed as ecosystem indicators.

\begin{tabular}{|c|c|c|}
\hline Coefficient/Method & Process/Indication/Application & Source \\
\hline $\begin{array}{l}\text { Area below the Normalized } \\
\text { Biomass Size Spectra (NBSS) }\end{array}$ & Total Community Biomass & Platt and Denman $(1977,1978)$ \\
\hline $\begin{array}{l}\text { Residual variation around the } b \\
\text { of the idealized linear size spectrum }\end{array}$ & Level of perturbation from the steady state & $\begin{array}{l}\text { Sprules and Munawar (1986), Choi et al. } \\
\text { (1999) }\end{array}$ \\
\hline $\begin{array}{l}\text { Residual variation around the } b \\
\text { of the idealized linear size spectrum }\end{array}$ & Overall productivity of the system & Sprules and Munawar (1986) \\
\hline Continuity in the size spectrum $b$ & Benthic-pelagic coupling in lakes & Echevarría et al. (1990) \\
\hline Continuity in the size spectrum $b$ & Benthic-pelagic coupling in continental shelf waters & Schwinghamer (1985), Warwick et al. (1986) \\
\hline a & $\begin{array}{l}\text { Biomass of primary producers or of the smallest size } \\
\text { group considered in the spectrum }\end{array}$ & Zhou (2006) \\
\hline$a$ & $\begin{array}{l}\text { To compare community biomass (only if they present } \\
\text { equal size spectra } b \text { ) }\end{array}$ & Sprules and Munawar (1986) \\
\hline$b$ & System overall productivity & Sprules and Munawar (1986) \\
\hline$b$ & Fishing exploitation & $\begin{array}{l}\text { Pope et al. (1987), Murawski and Idoine (1992), } \\
\text { Gobert (1994), Rice and Gislason (1996), }\end{array}$ \\
\hline$b$ & Sewage enrichment in lotic systems & $\begin{array}{l}\text { Gislason and Rice (1998), Bianchi et al. (2000) } \\
\text { de Bruyn et al. (2002) }\end{array}$ \\
\hline$b$ & $\begin{array}{l}\text { Predicting fish production from phytoplankton } \\
\text { standing stock }\end{array}$ & Moloney and Field (1985) \\
\hline$b$ & $\begin{array}{l}\text { Predicting fish production from primary and secondary } \\
\text { production }\end{array}$ & Sheldon et al. (1977), Borgmann (1983) \\
\hline$b$ & Mortality rate & Peterson and Wroblewski (1984) \\
\hline$b$ & Global warming & Yvon-Durocher et al. (2011) \\
\hline$b$ & Predator-prey mass ratio & $\begin{array}{l}\text { Silvert and Platt (1980), Camacho and Sole } \\
\text { (2001), Benoit and Rochet (2004) }\end{array}$ \\
\hline$b$ & Growth efficiency of individuals & $\begin{array}{l}\text { Silvert and Platt (1980), Camacho and Sole } \\
\text { (2001), Benolt and Rochet (2004) }\end{array}$ \\
\hline$b$ & Ecological efficiency & $\begin{array}{l}\text { Borgmann (1987), Boudreau and Dickie } \\
\text { (1992), Boudreau et al. (1991), Thiebaux and } \\
\text { Dickie (1992, 1993), Sprules and Goyke (1994) }\end{array}$ \\
\hline$b$ & Flow of persistent contaminants up the food web & $\begin{array}{l}\text { Borgmann and Whittle }(1983) \text {, Borgmann } \\
\text { (1985), Thomann }(1979,1981)\end{array}$ \\
\hline
\end{tabular}

approach can be used to analyse global properties of the ecosystem without having to study the diversity of organisms within it (Blanco et al. 1994). Size spectrum research has demonstrated that, in the absence of major disturbances, community size distributions show clear regularities (Sheldon et al. 1972, Platt 1985, Quiñones 1994, Law et al. 2009, Capitan and Delius 2010, Blanchard et al. 2011).

Typically, size spectrum coefficients are extracted by performing a least-squares linear regression on the log-transformed values of abundance ( $y$ axis: biomass normalized to the width of each size class) and body size ( $x$ axis: individual weight) (White et al. 2007, Clauset et al. 2009). Classes with zero observations are excluded, because $\log (0)$ is undefined (White et al. 2007). This technique is called the normalized biomass size spectrum (hereafter NBSS; Platt and Denman 1977, 1978, Blanco et al. 1994).

The coefficients of the NBSS, slope $(b)$ and intercept (a), have been proposed as quantitative indices of aquatic ecosystem structure (Sprules and Munawar 1986). Many authors suggest the use of NBSS slope as an indicator of the level of impact on a given ecosystem due to pollution (de Bruyn et al. 2002), habitat modification (Robson et al. 2005) or exploitation, especially when an ecosystem approach to fisheries (e.g. Shin et al. 2005, Jennings and Dulvy 2005, Garcia et al. 2012, see also Table 1) is adopted. The intercept, by contrast, has been proposed as an indicator of total biomass in the ecosystem (Sprules and Munawar 1986) and an indicator of primary producers biomass (Zhou 2006), or it has simply been ignored due to an observed correlation between the NBSS slope and intercept (Rice and Gislason 1996). However, it has not been proven that the correlation between these parameters is recurrent. Daan et al. (2005) proposed the use of the midpoint height rather than the intercept of the NBSS to characterize spectra. The use of the midpoint height is supposed to remove the influence of empirical correlations observed between $b$ and $a$ (Rice and Gislason 1996, Daan et al. 2005).

Several other approaches, however, have been developed for describing aquatic size spectra. Vidondo et al. (1997), suggested that the description of planktonic (or organismal in general) size distributions should be viewed in terms of distribution statistics, arguing in favour of using the Pareto distribution, which was originally used to describe the allocation of wealth among individuals (Pareto 1897) but is also widely used in many other disciplines to describe size distributions (e.g. energy release of seisms and gaps between them, masses in the solar system, population of cities within a country, see Vidondo et al. 1997 for more examples). Vidondo et al. (1997) indicated that the Pareto parameter $b\left(b_{\text {Pareto }}\right)$ is an unbiased estimator of the NBSS slope $(b)$. In addition, it avoids the need to group data by log size classes and the problem of empty size classes that may occur with NBSS. Sprules and Goyke (1994) showed that offset parabolas of uniform curvature provided an appropriate description of NBSS in Lakes Ontario and Michigan. An additive model was 
used rather than a simple linear model by De Eyto and Irvine (2007) to assess the status of shallow lakes.

Most of these new approaches and recommendations have not had a major impact on how empirical studies have described the size structure in marine and freshwater communities. Nevertheless, the Pareto distribution has been used to describe plankton communities (Quintana et al. 2002, Brucet et al. 2006, Finlay et al. 2007) and to assess the impact of trawling on benthic/demersal communities (Gómez-Canchong et al. 2011). A parabolic fit was also used by Finlay et al. (2007) when analyzing the factors driving the zooplankton size spectrum in lake communities.

In order to use size spectrum parameters as ecosystem indicators and/or components of more complex indicators, it is necessary to assess their properties and in particular, to determine whether they are independent of each other or have some level of correlation.

In this article we determine, in aquatic ecosystems, whether the slope and intercept of the NBSS are correlated using the following approaches: (i) theoretical analysis, (ii) virtual communities generated randomly on the basis of only statistical considerations, (iii) virtual food webs changing over time following a dynamic bioenergetic model. We explore the relationship between these two coefficients in previously published empirical size spectra. In addition, we analyze whether the Pareto distribution parameters are correlated or not, using approaches (i) and (ii).

\section{MATERIAL AND METHODS}

\section{Theoretical background}

Sheldon et al. (1972) postulated the linear biomass hypothesis, which states that the biomass in a pelagic community is uniformly distributed across the different geometrically arranged size classes. The mathematical formalism was developed by Platt and Denman (1977, 1978) and Silvert and Platt (1978) by means of $\beta$, a biomass density function based on the size of organisms. The biomass contained in a size class, defined by organisms with sizes $w_{l}$ and $w_{u}$, may be calculated as:

$$
B\left(w_{l}, w_{u}\right)=\int_{w_{l}}^{w_{u}} \beta(w) d w
$$

Sheldon's Linear Biomass Hypothesis states then:

$$
B(w, k w)=c \quad \text { if } k>1
$$

where $k$ is a geometric constant which represents the amplitude of each size class, and $c$ is a constant that depends on $k$ and the total amount of biomass in the ecosystem. $\beta$ is an allometric function, $a w^{b}$, and only meets the previous condition $(B=c)$ if $b=-1$. The nondimensional slope $b$ is an indicator of the proportion of biomasses between consecutive size classes, which is constant in this case (Blanco et al. 1994), i.e.

$$
c=\int_{w}^{k w} a w^{-1} d w=[a \ln w]_{w}^{k w}=a \ln k
$$

where $a$ is a coefficient expressed in the same units as numerical abundance, which indicates the amount of biomass averaged over a size range whose limits are in the geometric proportion $k$. Historically, coefficient $a$ has been related to the total biomass of the ecosystem (Sprules and Munawar 1986), but we will show below that the interpretation of this parameter is more complex than the interpretation of Sprules and Munawar. In case of $b \neq-1$ a more complex expression arises:

$$
c=\frac{a\left(k^{b+1}-1\right)}{b+1} w^{b+1}
$$

In this case, biomass on a geometric scale is not insensitive to body size and diminishes when $w$ increases if $b<-1$, or increases with $w$ if $b>-1$, and therefore the total biomass in the ecosystem is inversely related to the absolute value of $b$.

In relation to global properties, assuming $w_{0}$ as the minimum size of organisms and infinite as the maximum organism size, according to Equation (1) the total biomass $B$ of the ecosystem will be infinite if $b \geq-1$, whereas if $b<-1$ the total biomass is

$$
B=\frac{-a}{b+1} w_{0}^{b+1}
$$

which becomes simpler if we let $w_{0}$ be conventionally 1 (equivalent to using sizes relative to the smallest):

$$
B=\frac{-a}{b+1}
$$

Therefore, in those ecosystems where $b<-1$, the total biomass is directly related to $a$ and inversely related to the absolute value of $b$, from which we can deduce that the total biomass in the ecosystem would remain constant if and only if a change in one of the coefficients is compensated by an opposite change in the other.

Given a size-structured system, we may also define the abundance density function $\phi$, where the number of individuals $(N)$ included between sizes $w_{l}$ and $w_{u}$ is (Blanco et al. 1994):

$$
N\left(w_{l}, w_{u}\right)=\int_{w_{l}}^{w_{u}} \phi(w) d w
$$

This abundance density function $\phi$ is related to the biomass density function $\beta$ by the equation (Platt and Denman 1978)

$$
\phi(w)=\frac{\beta(w)}{w}
$$

where $\phi$ is also an allometric function, $\phi(w)=a w^{b-1}$, and accepting the premise that there is a non-zero minimum size in our system $\left(w_{0}>0\right)$, then since total biomass is always constrained when $b<-1$, the total number of individuals is always constrained regardless of $b$ : 


$$
\begin{gathered}
N=\int_{w_{0}}^{+\infty} \phi(w) d w=\int_{w_{0}}^{+\infty} a w^{b-1} d w= \\
=\frac{a}{b}\left[w^{b}\right]_{w_{0}}^{+\infty}=\frac{-a}{b} w_{0}^{b}
\end{gathered}
$$

This also becomes simpler using relative sizes $\left(w_{0}=1\right)$ :

$$
N=\frac{-a}{b}
$$

As before, in those ecosystems with $b<0$, the total abundance is directly related to $a$ and inversely related to the absolute value of $b$, and consequently the same compensation effect could occur between the two parameters, maintaining $N$ constant in the ecosystem, albeit with a different distribution of organism sizes.

The experimental approach to $\beta$ traditionally classifies the abundance of organisms in octave size classes (Platt and Denman 1978, Blanco et al. 1994), i.e. by means of the function $N(w, 2 w)$ in the notation of Equation (7). However, from the same equation a cumulative approach can be deduced if we consider the function

$$
N\left(w<w_{i}\right)=\int_{w_{0}}^{w_{i}} \phi(w) d w=\frac{a}{b}\left(w_{i}^{b}-w_{0}^{b}\right)
$$

which gives the number of individuals of size smaller than $w_{i}$. The complementary form $N\left(w<w_{i}\right)$ to $N$, which is the number of individuals of size larger than $w_{i}$, arranging Equations (9) and (11), is the Pareto function (Vidondo et al. 1997):

$$
N\left(w \geq w_{i}\right)=N-N\left(w<w_{i}\right)=\frac{-a}{b} w_{i}^{b}
$$
(10) to

This can be simplified using $w_{0}=1$ and Equation

$$
N\left(w \geq w_{i}\right)=N w_{i}^{b}
$$

The cumulative Pareto function is not strictly a "size spectrum", but has the same slope as $\beta$ and is more robust in its statistical properties; it deals directly with the individual sizes without grouping them into classes and can be extended to non-linear distributions (see Vidondo et al. 1997 for details). It is important to note that the abundance size spectrum and the Pareto distribution cannot be constructed when the sampling and/or analytical method used is only able to quantify aggregated biomass (e.g. gravimetric analysis, ATP content).

\section{Statistical model}

To check the statistical implications of the findings from the previous section, we simulated the sampling of individuals in a size-structured system using a Monte Carlo method (see Blanco et al. 1994 for an extended description). Following Equation (9), the size $\omega$ of a randomly sampled individual can be deduced from:

$$
\gamma=\frac{1}{N} \int_{w_{0}}^{\omega} \phi(w) d w
$$

where $\gamma$ is a uniformly distributed random variable $(0$, 1), so

$$
\omega=\left(w_{0}^{b}+\frac{b N}{a} \gamma\right)^{\frac{1}{b}}
$$

If we assume $w_{0}=1$, taking equation (10) and using $1-\gamma$ as equivalent to $\gamma$ (both being equally distributed), finally

$$
\omega=\gamma^{\frac{1}{b}}
$$

To avoid bias in the estimation of $b$, a very large number of individuals $\left(10^{6}\right.$ in most cases, $10^{5}$ in others, see below) were sampled and classified by size on an octave scale (i.e. base-2 logarithm). Furthermore, the elimination of empty size classes and those with few individuals located to the right of the first empty class also remove the tendency to overestimate $b$ (the "unexpected case effect", Blanco et al. 1994). The systematic error in the estimation of $a$ caused by the selection of a nominal size for each class, was corrected by using the lower limit as the nominal size and multiplying the coefficient $a$ by the correction factor $1 / \ln 2$ in case of $b=-1$, or $(b+1) /\left(2^{b+1}-1\right)$ in the case of $\mathrm{b} \neq-1$ (see Blanco et al. 1994 for details on the effect of nominal size, optimum nominal size and correction factors). In some cases, a cumulative Pareto distribution (Vidondo et al. 1997) was built with the same data to avoid the classification into groups (with only $10^{5}$ individuals due to computation time) and to serve as a comparison to the typical spectrum approach.

To check possible influences of $b$, three types of simulation were performed: (A) keeping a constant $b=-1$, (B) picking $b$ from a normal distribution with mean $b=-1$ and $\sigma=0.25$, and (C) picking $b$ from a uniform distribution (between $-1.5,-0.5$ ) (Fig. 1). The central value of -1 was chosen because of the natural tendency of pelagic ecosystems around this slope (e.g. Kerr and Dickie 2001). In order to evaluate the importance of sample size, a B-type experiment was conducted with $4 \cdot 10^{5}$ samples of different size in the range 100 to $10^{6}$ individuals.

\section{Dynamic bioenergetic model}

The food web models were built considering virtual allometrically derived species (hereafter VADS; Gómez-Canchong et al. 2013). It is important to note that in this formulation, a VADS corresponds to an aggregation of individuals of the same body size, independent of their taxonomy. The population dynamics within these food webs follows a model based on 


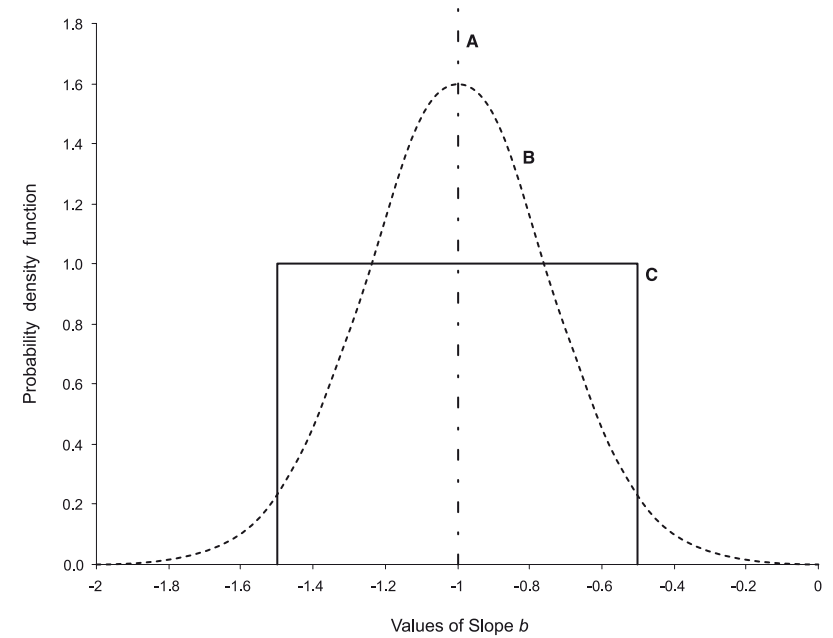

FIG. 1. - Three ways to generate the theoretical value of $b$ of the system to be sampled. The coefficient $b$ for Monte Carlo simulation was fixed at $-1(\mathrm{~A})$ or was randomly chosen from a normal distribution with mean $=-1$ and $s . d .=0.25(\mathrm{~B})$ or from a uniform distribution between -1.5 and $-0.5(\mathrm{C})$.

bioenergetic and allometric reasoning, which involves parameterizing a model using power functions of individual body mass (Yodzis and Innes 1992). The model was updated by Brose et al. $(2005,2006)$ with new allometric coefficients (Brown et al. 2004) and extended to multi-species systems (Williams and Martinez 2004). Changes in the relative biomass densities of primary producer VADS (Eq. 17) and consumer VADS (Eq. 18) are described as follows:

$$
\begin{aligned}
B_{i}^{\prime}=r_{i}\left(M_{i}\right) G_{i} B_{i}-\sum_{j=\text { consumers }} \frac{x_{j}\left(M_{j}\right) y_{j} B_{j} F_{j i}(B)}{e_{j i} f_{j i}} \\
B_{i}^{\prime}=-x_{i}\left(M_{i}\right) B_{i}+\sum_{j=\text { resources }} x_{i}\left(M_{i}\right) y_{i} B_{i} F_{j i}(B)- \\
-\sum_{j=\text { consumers }} \frac{x_{j}\left(M_{j}\right) y_{j} B_{j} F_{j i}(B)}{e_{j i} f_{j i}}
\end{aligned}
$$

In these equations, $B_{i}$ is the biomass of population $i, r_{i}$ is the mass-specific maximum growth rate of $i, M_{i}$ is the body mass of individuals within population $i, G_{i}$ is $i$ 's logistic net growth rate of producers, where $G_{i}=$ $1-(B i / K)$ and $K$ is $i$ 's carrying capacity, $x_{i}$ is $i$ 's massspecific metabolic rate, $y_{i}$ is $i$ 's maximum consumption rate relative to its metabolic rate, and $e_{i j}$ is $i$ 's assimilation efficiency when consuming population $j$.

The functional response, $F_{i j}$, quantifies the per capita consumption rates of predators $(i)$ depending on prey density $(j)$ :

$$
F_{i j}=\frac{\varpi_{i j} B_{j}^{h}}{B_{0}^{h}+c_{i} B_{i} B_{0}^{h}+\sum_{k=\text { resources }} \varpi_{i k} B_{k}^{h}}
$$

where $\varpi_{i j}$ is the weight factor representing the proportion (0-1) of $i$ 's attack rate targeted to prey $j, B_{0}$ is the half-saturation density, $h$ is the Hill coefficient (Real 1977) and $c$ quantifies predator interference. The Hill coefficient is a scaling exponent that relates to the handling time needed to kill, ingest and digest a resource individual (Real 1977). The predator interference term in the denominator quantifies the degree to which individuals within population $i$ interfere with one another's consumption activities, which reduces $i$ 's per capita consumption if c >0 (Beddington 1975, DeAngelis et al. 1975, Skalski and Gilliam 2001).

We calculated the average body masses of populations depending on their trophic level according to

$$
\log _{10} M_{i}=T L^{d}+r s d
$$

where $d$ is the exponent of the relationship between the trophic level and the body mass (TL-M slope) of each VADS, and $r s d$ is a stochastic variable that is randomly sampled from a normal distribution (mean $=1$, $\mathrm{sd}=2$ ). This calculation implies that predators are most often larger than their prey, which is consistent with the structure of pelagic systems, where body size is considered to be the main constraint on the predator's ability to catch its prey (Lundvall et al. 1999, Cury et al. 2003), unlike terrestrial systems where predators of higher trophic levels are able to feed on prey of greater body size but lower trophic level. For greater detail on the model, see Brose et al. (2005, 2006), Berlow et al. (2009) and Gómez-Canchong et al. (2013).

In order to ensure that the use of mean body size of the VADS adequately represents the individual size distribution of the community, a sufficiently large number of VADS is required. If we increase the number of populations to infinite, the formulations must converge (Gómez-Canchong et al. 2013). In order to determine an appropriate number of VADS to be used, we ran 1680 simulations over 800 time steps, 20 for each number of VADS from 7 to 90 (Fig. 2). We observed that increasing the number of VADS over 40 had no effect

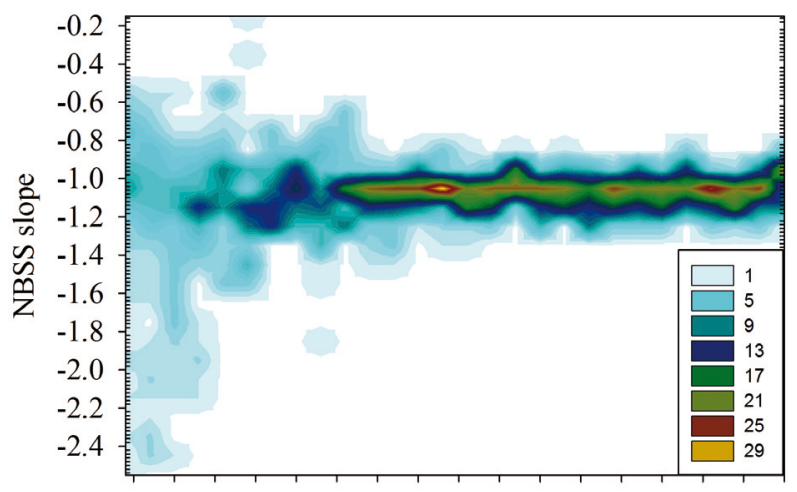

1015202530354045505560657075808590 Number of VADS

FIG. 2. - Behaviour of the slope $b$ of the normalized biomass size spectrum (NBSS) of the dynamic approach when the number of virtual allometrically derived species (VADS) considered in the simulations is increased. The color scale indicates how many food webs have the same NBSS slope. 

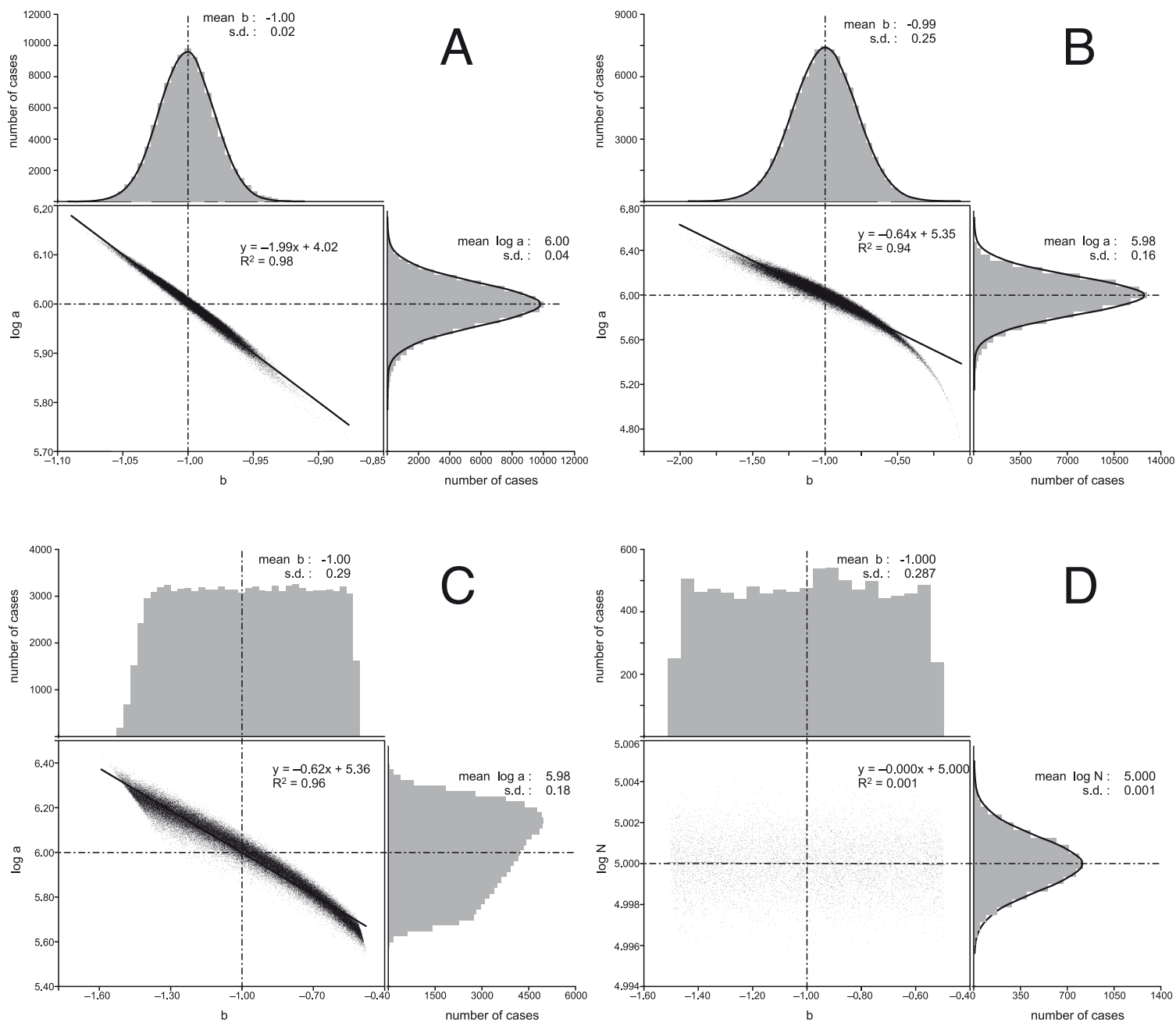

FIG. 3. - A: relationship between spectrum coefficients ( $\log a$ vs. slope $b$ ) of $10^{5}$ simulations (each with a set of $10^{6}$ organisms) according to Equation (16) with theoretical $b$ fixed at -1 . B: idem with theoretical $b$ randomly chosen from a normal distribution with mean $=-1$ and s.d. $=0.25$. C: idem with theoretical $b$ randomly chosen from a uniform distribution between -1.5 and 0.5 . $\mathrm{D}$ (for comparison with the spectrum approach): relationship between $N$ and $b$ of Pareto's cumulative distribution (Eq. 13) of $10^{4}$ simulations (each with a set of $10^{5}$ organisms) with theoretical $b$ as in situation C. The distribution of cases is shown beside respective axis, with the empirical mean and s.d.

on the simulation outputs (NBSS coefficients). Taking this into consideration, we decided to use networks with 70 VADS.

We ran $10^{4}$ simulations over 800 time steps. A time step represents the turnover rate of a phytoplankton cell, which corresponds approximately to one day. For each run we generated a niche model food web, in which species are constrained to consume all prey species within one range of sizes whose randomly chosen centre is less than the consumer's size (Williams and Martinez 2000), assigning random initial biomass densities to populations while systematically varying the following food web variables: connectance (from 0.075 to 0.250 ), functional response type (Hill coefficients from a uniform distribution between 1 and 2), the strength of predator interference $\left(c_{i}\right.$ from a uniform distribution between 1 and 2), the metabolic types of VADS (invertebrates or ectothermal vertebrates), and the carrying capacity (logistic growth) of the producer VADS ( $k$ from 0.5 to 3.5 ). The spectra generated using virtual food webs were not constrained to $b=-1$ in the initial biomass assignation.

To compare among the different food webs, the first quarter of the time steps of each simulation run was not used in the construction of the NBSS in order to avoid the effects of transient dynamics. Choosing biomass densities over this time period allowed initial transient dynamics to settle down and capture the inherent variability among runs, thus increasing consistency with empirical studies (Brose et al. 2006). Prior work by Berlow et al. (2009) demonstrated that this length of the time series is sufficient to obtain stable mean biomass densities from populations that are independent of initial biomass densities. By contrast, all the time steps of each simulation run were taken into account when analyzing the relationship between the coefficients in each food web over time.

We also analyzed the behaviour of NBSS coefficients in some selected time series by calculating the NBSS for each time step. At each time step, we calcu- 
lated the total biomass of the community from the area below the NBSS from arbitrarily chosen $\log _{10}$ bodysizes, between one and five relative units, by means of the integral under the curve

$$
\operatorname{TotalBiomass}\left(w_{l}, w_{u}\right)=\int_{w_{l}=1}^{w_{u}=5} a w^{b} d w=\left[\frac{a}{b+1} w^{b+1}\right]_{1}^{5}
$$

\section{Spectrum coefficients from published size spectra}

We reviewed references in which aquatic size spectra data were available, especially those including spatial and temporal variability. We calculated the correlation between the spectrum coefficients in each study. Studies in which only commercial species were sampled and not the whole fish assemblage were not taken into account. The spectra analyzed corresponded to NBSS or number size spectra (NSS), in which the number of individuals per size class is plotted instead of biomass. Both size spectra are equivalent if the former is arranged on an octave scale and the latter on an arithmetic scale (Platt and Denman 1978). When $a$ or $b$ were not directly reported, we obtained them graphically from figures using Zoo/PhytoImage freeware.

\section{RESULTS}

The statistical models always exhibited strong correlations between the two NBSS coefficients for any theoretical $b$ distribution (Fig. 3A, B, C). In experiments $\mathrm{A}$ and $\mathrm{B}$, respectively, with fixed and normal theoretical values of $b$, the frequency of coefficients of sampled spectra followed normal distributions around the theoretical mean value $(-1.00$ for $b, 6.00$ for $\log a)$. In experiment $\mathrm{C}$, the frequency of coefficients showed the same mean values, but now with a non-Gaussian distribution of cases. By comparison, the equivalent Pareto cumulative approach to experiment $\mathrm{C}$ showed no relationship between $N_{\text {Pareto }}$ and $b_{\text {Pareto }}$, with an accurate prediction of both parameters (the behaviour of $N_{\text {Pareto }}$ being Gaussian, in spite of the uniform distribution of $b_{\text {Pareto }}$ ), even with fewer simulations and fewer sampled organisms. The regression between $\log a$ and $b$ was around -2.0 in the fixed $b$ experiment and showed slopes around -0.6 in experiments with a wider $b$ range (B, C), which also showed a non-linear tendency as $b$ approached zero. The influence of sample volume on the $\mathrm{a} / \mathrm{b}$ ratio is shown in Figure 4 as an almost perfect coincidence between the two variables.

The virtual food web modelling also showed that the NBSS parameters were inversely correlated when different food webs were compared (Fig. 5). This relationship presented two states according to the value of the slope $b$ :

(i) Communities with $b<-1$ : in these cases the relationship between the NBSS parameters $b$ and $a$ showed a strong correlation (Fig. 5; r=-0.8806; $\mathrm{p}<0.0001$ ).

(ii) Communities with $b>-1$ : these represent flatter biomass pyramids, which according to Makarieva et al

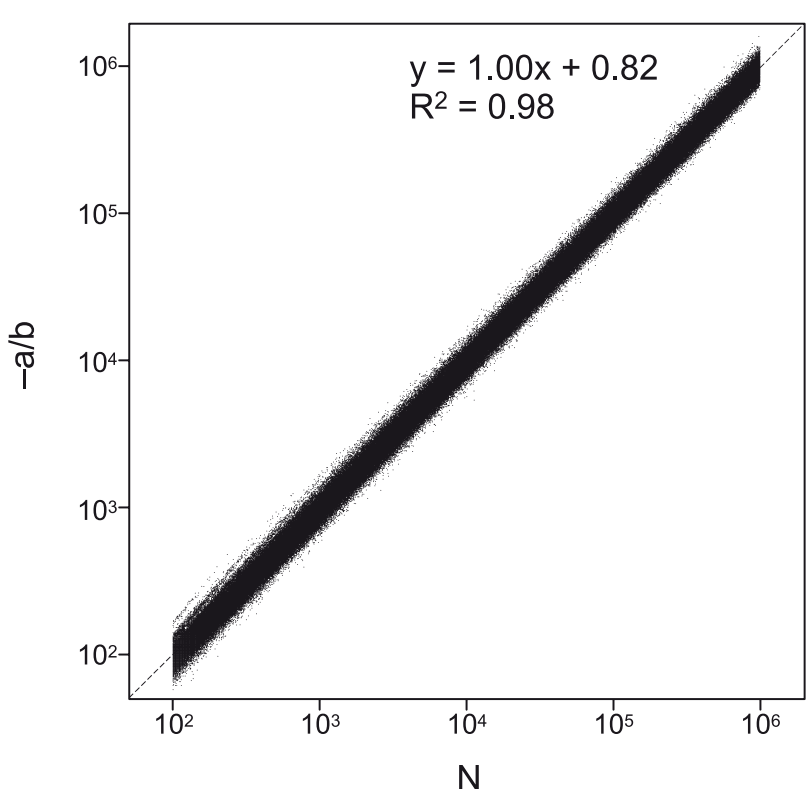

FIG. 4. - Comparison between volume of sample $(N)$ and ratio $-a / b$ of respective spectra of $4 \cdot 10^{5}$ cases. $N$ varied randomly between 100 and $10^{6}$ individuals. The correlation was made with non-logarithmic values.

(2004) are more unstable than steeper biomass pyramids. They also displayed a strong correlation between $b$ and $a$ parameters (Fig. 5; $\mathrm{r}=-0.9082 ; \mathrm{p}<0.0001$ ).

We found a similarly strong inverse relationship between the NBSS parameters $b$ and $a$ when tracking the relationship throughout the time series of individual food webs (see Fig. 6A, B for examples). Surprisingly, we also found some communities whose NBSS lacked a relationship between the $b$ and $a$ coefficients (see Fig. 6C for an example). Interestingly, all of the latter cases were food webs with either a type II functional response or with $b>-1$. However, not all food webs with type II functional responses or with $b>-1$ lacked a relationship between the NBSS parameters.

Empirical results reported in the literature (Tables 2 and 3 ) show that in most cases (both com-

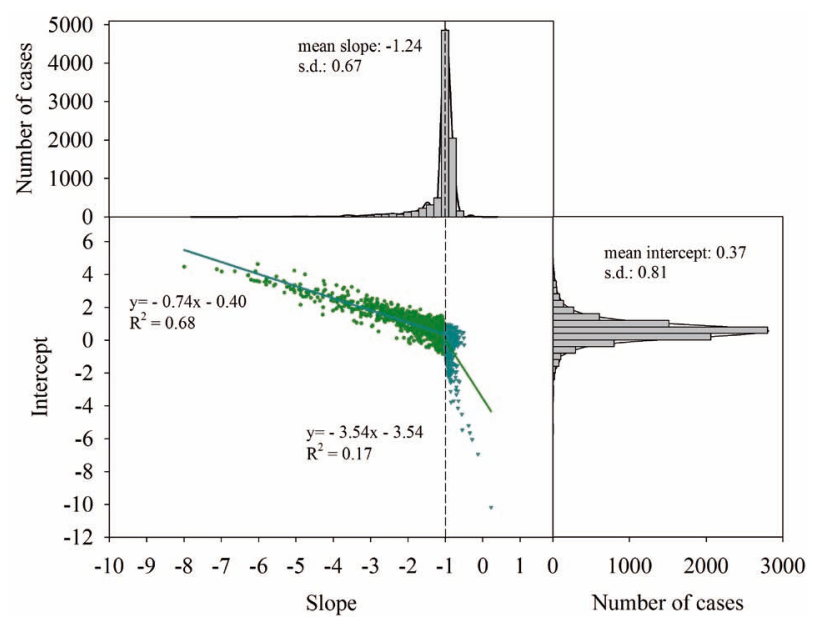

FIG. 5. - Relationship between parameters $b$ and $a$ of the normalized biomass size spectra of $10^{4}$ simulated food webs. 
A
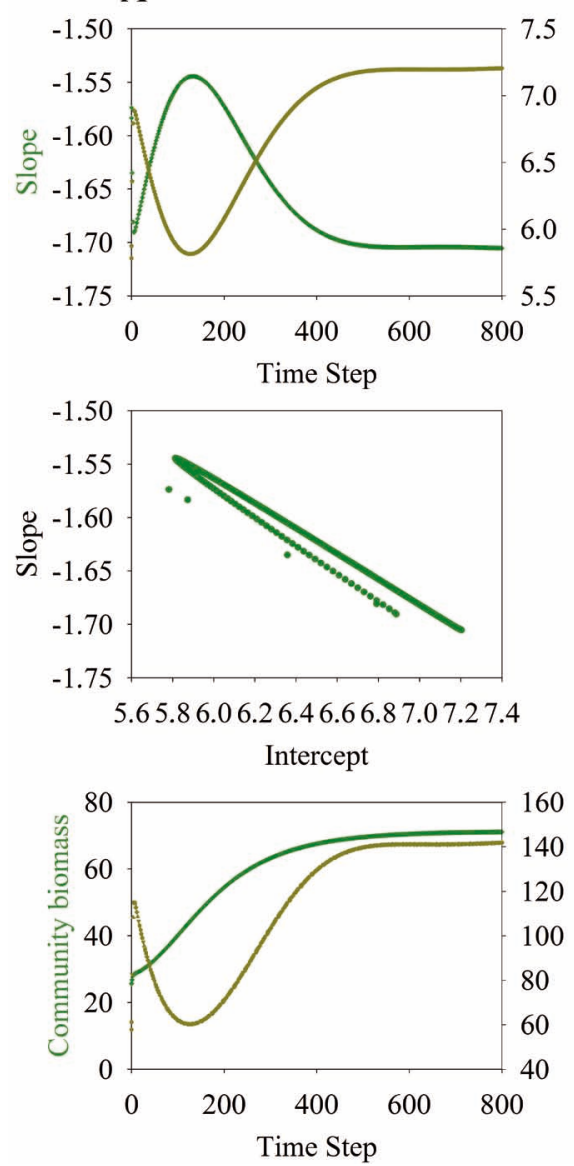

B
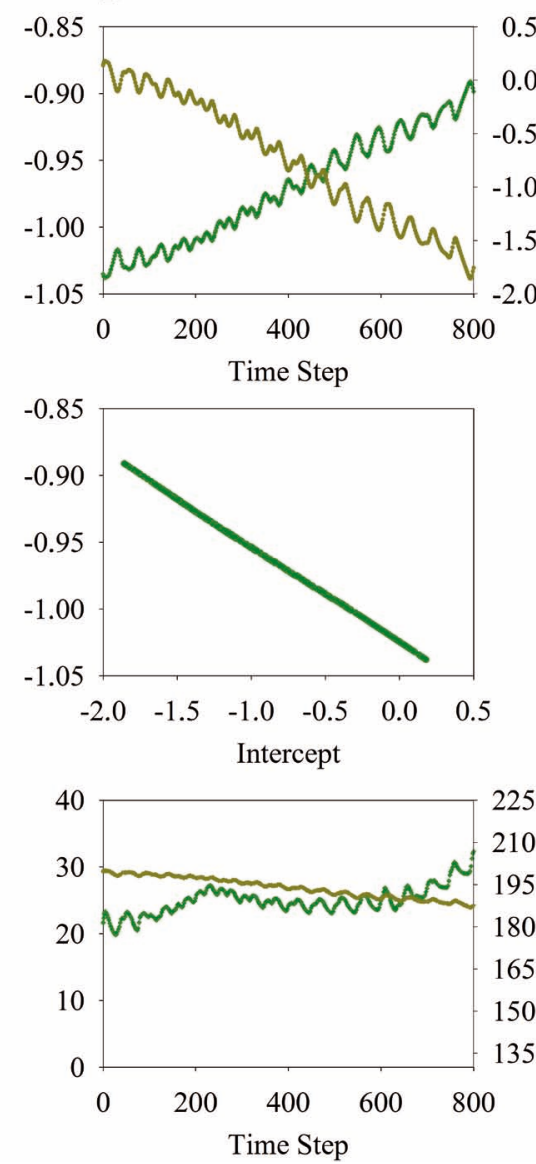

$\mathrm{C}$
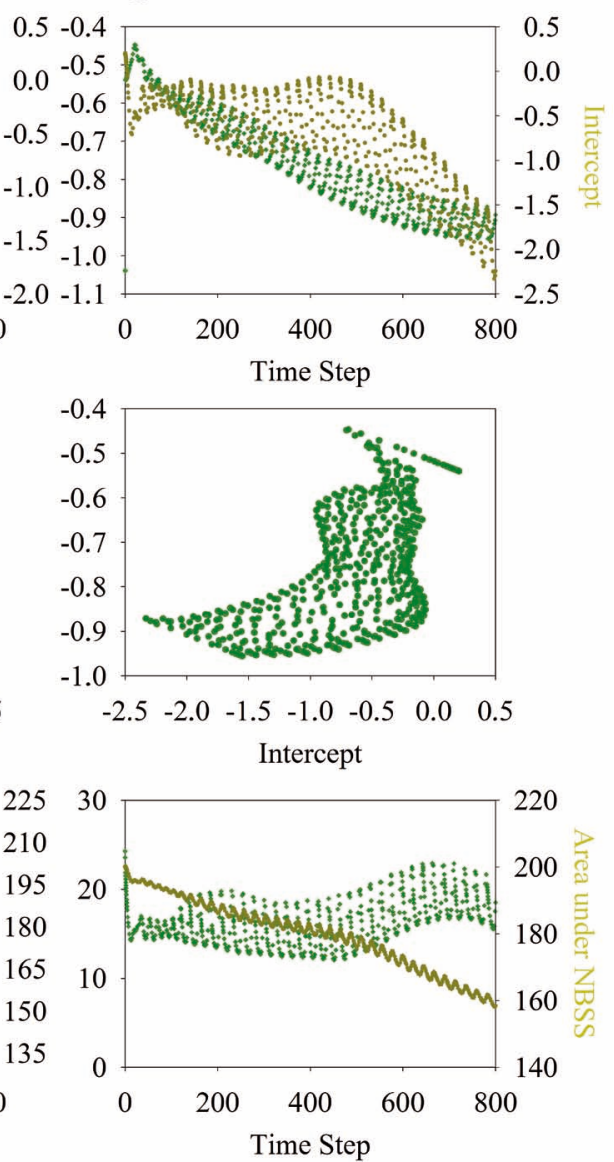

FIG. 6. - Examples of the behaviour of the coefficients $b$ (green line) and $a$ (yellow line) of normalized biomass-size spectra (upper panels), the relationship between the same two coefficients (medium panels), and comparison between the two approaches used to measure the total community biomass (lower panels), summing the biomass of all the species (green line), and calculating the surface area under the normalized biomass size spectra (yellow line). Panels $\mathrm{A}$ and $\mathrm{B}$ represent regular biomass pyramids, and panel $\mathrm{C}$ an inverted biomass pyramid.

paring between sites and over time) there was a negative correlation between the NBSS parameters $b$ and $a$ (e.g. Macpherson et al. 2002, Binduo and Xianshi 2005), although there were also cases in which this correlation was positive (e.g. Rodriguez and Mullin 1986, Sprules and Munawar 1986) or in which $b$ and $a$ of the size spectra were not correlated (e.g. Quiroga et al. 2005, Dimech et al. 2008). We observed this lack of correlation almost exclusively when comparing size spectra from different places (Table 2), in other words, when comparing between different communities.

\section{DISCUSSION}

The functional dependence of $N=-a / b$ should appear in the background of any sampling system (either real or simulated) if the size structure is linear with $b<0$, as occurs in most pelagic ecosystems. In ideal systems, the sample volume will mainly affect the intercept $a$, with $b$ being a more robust parameter independent of individual abundance and more related to the structure of the size distribution. It is expected that a system viewed through different windows of different sample volumes would exhibit the following relationship:

$$
-b=\frac{N_{1}}{a_{1}}=\frac{N_{2}}{a_{2}}
$$

where $N_{1}$ and $N_{2}$ are the abundance of organisms in each sample, as shown in Figure 4. Likewise, those systems with similar abundances (e.g. when analyzing the same community at different times) should exhibit the same $a / b$ ratio, which could be reached with very different combinations of parameters, from steep sizestructures (many small, few large organisms: high absolute values of $a, b$ ) to flatter distributions (low absolute values of $a, b)$ and to Sheldon's Linear System (biomass equally distributed among small and large organisms, with $b=-1, a=N)$. Therefore, although $a$ and $b$ are related, they do not carry the same information about the ecosystem.

From a statistical standpoint, the correlation between the parameters of the NBSS is due to the separation into classes with a barycentre that is not located at the origin of the size axis and is independent of the situ- 
TABLE 2. - Pearson correlations between the observed $b$ and $a$ of size spectra comparing different locations. Significant p-values and positive correlations in bold. NSS, Number Size Spectra; NBSS, Normalized Biomass Size Spectra.

\begin{tabular}{|c|c|c|c|c|c|c|c|}
\hline \multicolumn{2}{|c|}{ Correlation p-value } & \multirow{2}{*}{$\frac{\text { Groups included }}{\text { Infaunal }}$} & \multirow{2}{*}{$\frac{n}{21}$} & \multirow{2}{*}{$\frac{\text { Geographic location }}{\text { North Sea }}$} & \multirow{2}{*}{$\frac{\text { Spectra }}{\text { NBSS }}$} & \multirow{2}{*}{$\begin{array}{c}\text { Observations } \\
\text { Different trawling disturbance }\end{array}$} & \multirow{2}{*}{$\begin{array}{l}\text { Source } \\
\text { Jennings et al. } 2001\end{array}$} \\
\hline & 0.0037 & & & & & & \\
\hline & & Polychaete & 21 & North Sea & NBSS & Different trawling disturbance & Jennings et al. 2001 \\
\hline 247 & $<0.0001$ & Epifaunal & 21 & North Sea & NBSS & Different trawling disturbance & Jennings et al. 2001 \\
\hline 477 & 0.0039 & $\begin{array}{l}\text { From bacteria to } \\
\text { mesozooplankton }\end{array}$ & 9 & Central gyre.NW Atlantic & NBSS & Biomass in Biovolume & Quiñones et al. 2003 \\
\hline & 0.0079 & Microplankton & 20 & Central gyre.NW Atlantic & NBSS & Biomass in Biovolume & Quiñones et al. 2003 \\
\hline & & Microplankton & 16 & & & & et al. 2003 \\
\hline 0.9699 & $<0.0001$ & $\begin{array}{l}\text { From bacteria to } \\
\text { mesozooplankton }\end{array}$ & 9 & Central gyre.NW Atlantic & NBSS & Biomass in Carbon Units & Quiñones et al. 2003 \\
\hline-0.9947 & $<0.0001$ & Demersal fish & 6 & Worldwide & NSS & $\begin{array}{c}\text { Trawling surveys from demersal } \\
\text { fishing grounds }\end{array}$ & Bianchi et al. 2000 \\
\hline-0.8333 & 0.0008 & Fish & 12 & $\begin{array}{l}\text { Saint Lawrence River, } \\
\text { US/CA }\end{array}$ & NBSS & Enriched by sewage & de Bruyn et al. 2002 \\
\hline-0.6603 & 0.0747 & Demersal community & 8 & Malta & NBSS & $\begin{array}{l}\text { Inside and outside a } \\
\text { Fishery Management Zone }\end{array}$ & Dimech et al. 2008 \\
\hline-0.3952 & 0.0374 & Invertebrates & 29 & $\begin{array}{l}\text { Lizard Peninsula, } \\
\text { Cornwall, UK }\end{array}$ & NBSS & $\begin{array}{l}\text { Different macrophyte } \\
\text { physical complexity }\end{array}$ & McAbendroth et al. 2005 \\
\hline 0.521 & 0.1218 & Plankton & 10 & Atlantic Ocean & NBSS & Latitudinal variation & San Martin et al. 2006 \\
\hline & $<0.0001$ & ittoral Ro & 12 & NW Mediterr & & Protected Area & al. 2002 \\
\hline-0.7798 & 0.0028 & Littoral Rocky Fish & 12 & NW Mediterranean & NBSS & Unprotected Area & Macpherson et al. 2002 \\
\hline 0.9187 & 0.0275 & $\begin{array}{l}\text { Macro- and } \\
\text { meiobenthos }\end{array}$ & 5 & Southern Baltic Sea & NBSS & $\begin{array}{l}\text { Different sediment characteristics. } \\
\text { Biomass in Carbon Units }\end{array}$ & Drgas et al. (1998) \\
\hline-0.2863 & 0.6404 & Macrobenthos & 5 & Humboldt Current System & NBSS & Oxygen Minimum Zone & Quiroga et al. 2005 \\
\hline 0.8330 & 0.0200 & Plankton & 7 & $\begin{array}{l}\text { Great Lakes and North } \\
\text { Pacific Central Gyre }\end{array}$ & NBSS & $\begin{array}{l}\text { Different productivity } \\
\text { and level of perturbation }\end{array}$ & $\begin{array}{l}\text { Sprules and Munawar } \\
1986\end{array}$ \\
\hline
\end{tabular}

TABLE 3. - Pearson correlations between the observed $b$ and $a$ of size spectra from the same location during a time series. Significant p-values and positive correlations in bold. NSS, Number Size Spectra; NBSS, Normalized Biomass Size Spectra.

\begin{tabular}{|c|c|c|c|c|c|c|c|}
\hline Correlation & p-value & Groups Included & $\mathrm{n}$ & Geographic location & Type of spectra & Observations & Source \\
\hline-0.8207 & $<0.0001$ & Fish & 17 & North Sea & NSS & Trawled area & Rice and Gislason (1996) ${ }^{\mathrm{a}}$ \\
\hline 0.1972 & 0.4184 & Fish & 19 & North Sea & NSS & $\begin{array}{l}\text { Data from multi-species virtual } \\
\text { opulation analysis. Trawled area }\end{array}$ & $\begin{array}{l}\text { Rice and Gislason } \\
(1996)^{\mathrm{a}}\end{array}$ \\
\hline 0.9234 & $<0.0001$ & Microplankton & 18 & $\begin{array}{l}\text { North Pacific } \\
\text { Central Gyre }\end{array}$ & NBSS S & Steady state oceanic ecosystem & $\begin{array}{l}\text { Rodriguez and Mullin } \\
1986\end{array}$ \\
\hline-0.9629 & $<0.0001$ & Fish & 14 & Yellow Sea & NSS & Fishing area & Binduo and Xianshi 2005 \\
\hline-0.9833 & $<0.0001$ & Demersal Fish & 25 & Eastern Bering Sea & NSS & Fishing area & Bartkiw et al. 2007 \\
\hline-0.9996 & $<0.0001$ & Fish & 10 & - & NSS & Fishing effect modelling & Shin and Cury 2004 \\
\hline-0.8868 & $<0.0001$ & Benthic fish & 27 & Benguela System & NBSS & $\begin{array}{l}\text { High and low productivity } \\
\text { centres }\end{array}$ & $\begin{array}{l}\text { Macpherson and Gordoa } \\
1996\end{array}$ \\
\hline-0.9504 & $<0.0001$ & Lake Benthos & 15 & - & NBSS & $\begin{array}{l}\text { Gradient of predation pressure } \\
\text { in experimental lakes }\end{array}$ & Blumenshine et al. 2000 \\
\hline
\end{tabular}

a Note that the size spectra from empirical survey data show a correlation between the $b$ and $a$; however, the size spectra derive from multispecies virtual population analysis lacks such a relationship.

ation (narrower or wider ranges for theoretical $b$ ). At narrow $b$ ranges, the relationship is linear, whereas at wider $b$ ranges the relationship falls asymptotically to zero when $b$ tends to zero, to account for the spread of a finite abundance along an infinite size axis (flat spectrum, very rare in nature since it represents an inverted biomass pyramid). Another way to build NBSS in classes and avoid the correlation between coefficients is by fixing the midpoint of size distributions at zero (Daan et al. 2005) and then using its slope and height to characterize the NBSS. A better statistical approach is the use of a function with independent parameters (like the Pareto distribution), but the common use of size classes, as is the case in traditionally constructed size spectra, may be easier to interpret from an ecological standpoint (e.g. Kerr and Dickie 2001, Marquet et al. 2005), particularly in pelagic ecosystems (e.g. Marañón et al. 2007) in which cumulative methods were proposed in the last century (e.g. Vidondo et al. 1997) but have not gained many users yet. Also, nonparametric approaches to size distributions (Quintana et al. 2008) were proposed to avoid the correlation of parameters and the effect of units on the comparison of ecosystems, but the resulting standardized measure is only useful for evaluating the size diversity and does not permit the deduction of global properties (biomass, metabolism, etc.), as do the classic parametric functions (e.g. Blanco et al. 1998).

The results of the dynamic modelling confirmed the results of the statistical model, showing that the size spectra of food webs changing over time tend to display a strong correlation between the two size spectrum parameters (Fig. 6). In addition, the results of the virtual food web modelling (Fig. 5) also displayed a strong correlation when the coefficients were compared between food webs with a different link 
structure (who eats whom), suggesting that changes in the link structure are unable to affect the relationship between the two spectrum parameters. Only a significant change in $b$ is able to modify this relationship (i.e. if $b$ is $>$ or $<$ than -1 ). A slope change towards more positive $b$ values $(b>-1)$ modifies the shape of the biomass pyramid because beyond this threshold the biomass pyramid becomes inverted; in other words, biomass would be larger at the top of the pyramid than at its base. The existence of inverted biomass pyramids seems paradoxical, although they are well known to exist in planktonic communities (Wang et al. 2009), because in a closed ecosystem each trophic level of the energy pyramid is roughly $10 \%$ of the level below it (Odum 1971, Pauly and Christensen 1995), so inverted energy pyramids cannot endure (Wang et al. 2009). Therefore, an inverted biomass pyramid or flatter spectrum should be very unstable and unable to persist for long.

The dynamic modelling results (Figs 5 and 6) also suggest that communities with steeper negative $b$ do not have a smaller amount of community biomass, but rather biomass is lower in larger size classes and higher in smaller size classes. On the other hand, flatter size distributions can reduce the total biomass of the community when the value of $b$ crosses the -1.0 threshold, becoming less negative and eventually transforming the size distribution into an inverted biomass pyramid with a consequently lower level of stability (Makarieva et al. 2004). Our simulations also show that when the producers in the system maintain constant carrying capacity, increases in $a$ of the NBSS take place while $b$ decreases, even when community biomass remains constant. Total community biomass is more associated with the area under the NBSS (i.e. the integral below the NBSS) than with the $a$ coefficient (Fig. 6). However, this relationship is lost when the NBSS does not adequately represent the size structure (i.e. low correlation coefficient) in some extreme cases, such as the extinction of all individuals in a size class or when the TL-M slope presents values close to zero. The lack of NBSS linearity precludes the use of the integral under the NBSS (Platt and Denman 1977, 1978) or the height of the size spectrum (Daan et al. 2005) to estimate ecosystem biomass.

The correlation between $a$ and $b$ in the statistical model was very high (Fig. 3a), indicating a functional relationship between these coefficients, which was expected because all the samples came from virtual communities where $a=-b N$ and the total number of individuals $(N)$ was the same. However, on the basis of our results from the dynamic modelling of virtual food webs and on the analysis of empirical spectra reported in the literature, we observe that there is not a unique relationship between these two coefficients, and consequently it is not proper to assume that they are necessarily correlated. Therefore, we cannot expect communities with different $N$ (total abundance) to exhibit the same relationship between the two coefficients. Indeed, reviewing the empirical data published on size spectra (Tables 2 and 3 ) shows that $b$ and $a$ are mostly correlated in size spectra from the same community over time, but not necessarily when data from different sites are compared or pooled.

In all cases exclusively involving fish assemblages under fishing pressure, strong negative correlations were found between the $b$ and $a$ coefficients (Tables 2 and 3). It is important to note that when working only with fish assemblages, the analysis is restricted to a narrow range of sizes and all organisms possess common production efficiencies (Boudreau and Dickie 1992). Dickie et al. (1987) classified the $b$ of these assemblages of species with similar production efficiencies as "secondary slopes" and suggested that at the level of this secondary scaling ecological principles (e.g. fishing effects) control the size structure of the assemblage.

Several authors have proposed that fishing makes the slope of the NBSS steeper (i.e. more negative), because it selectively removes larger individuals and reduces survival (Gislason and Rice 1998, Bianchi et al. 2000). Obviously, this is based on the assumption that the linearity of the NBSS is not lost. However, ecosystems which are far from steady state can display nonlinear NBSS (Quiñones 1994, Rodriguez 1994), and high levels of fishing may cause the size distribution of the biota to be drastically modified (Jennings and Kaiser 1998). On the other hand, Benoit and Rochet (2004), Shin and Cury (2004) and Gómez-Canchong et al. (2011) suggested that fishing effects may be better captured by the curvature of the size spectrum than by its $b$. Consequently, it is important to explore the use of non-linear size spectra (e.g. Pareto distribution) as a tool for analyzing community dynamics in heavily fished ecosystems.

In conclusion, to characterize any aquatic system at least two parameters are necessary from the NBSS triad $(N, a, b)$, or other parameters derived from them. This is important for designing ecosystem indicators based on biomass size spectra, especially considering that most disturbances affecting ecosystems (e.g. fishing, pollution) tend to reduce the total abundance of individuals in the system, changing the relationship between $a$ and $b$ or $N$ and $b$, and consequently in such cases it is necessary to analyze the community size structure using both NBSS parameters ( $a$ and $b$ ) and a global property $(N$ or $B)$.

\section{ACKNOWLEDGEMENTS}

This research was funded by the COPAS-Sur Austral Programme (Programa Bicentenario de Ciencia y Tecnología Grant PFB-31/2007, CONICYT, Chile). J.M. Blanco was funded by Malaspina 2010: Expedición de Circunnavegación Cambio Global y Exploración de la Biodiversidad del Océano Global, ref. CSD-2008-00077, Spain. 


\section{REFERENCES}

Bartkiw S., Boldt J., Livingston P., Walters G., Hoff G. 2007. Indicators of size diversity in the eastern Bering Sea. Copenhagen Denmark Ices 2007/E: 21.

Beddington J.R. 1975. Mutual interference between parasites or predators and its effect on searching efficiency. J. Anim. Ecol. 44: 331-340.

Benoit E., Rochet M.J. 2004. A continuous model of biomass size spectra governed by predation and the effects of fishing on them. J. Theor. Biol. 226: 9-21.

Berlow E.L., Dunne J.A., Martinez N.D., Stark P.B., Williams R.J. Brose U. 2009. Simple prediction of interaction strengths in complex food webs. Proc. Natl. Acad. Sci. U.S.A. 106: 187-191.

Bianchi G., Gislason H., Graham K., Hill L., Jin X., Koranteng K., Manickchand-Heileman S., Payá I., Sainsbury K., Sanchez F., Zwanenburg K. 2000. Impact of fishing on size composition and diversity of demersal fish communities. ICES J. Mar. Sci. 57: 558-571.

Binduo X., Xianshi S. 2005. Variations in fish community structure during winter in the southern Yellow Sea over the period 1985-2002. Fish. Res. 71: 79-91.

Blanchard J.L., Jennings S., Law R., Castle M.D., McCloghrie P. Rochet M.J., Benoit E. 2009. How does abundance scale with body size in coupled size-structured food webs? J. Anim. Ecol. 78: $270-280$.

Blanchard J.L., Law R., Castle M.D., Jennings S. 2011. Coupled energy pathways and the resilience of size-structured food webs. Theor. Ecol. 4(3): 289-300.

Blanco J.M., Echevarría F., García C. 1994. Dealing with size spectra: some conceptual and mathematical problems. Sci. Mar. 58 17-29.

Blumenshine S.C., Lodge D.M., Hodgson J.R. 2000. Gradient of fish predation alters body size distributions of lake benthos. Ecology 81(2): 374-386.

Borgmann U. 1983. Effect of somatic growth and reproduction on biomass transfer up pelagic food web as calculated from particle-size-conversion efficiency. Can. J. Fish. Aquat. Sci. 44: $136-140$

Borgmann U. 1985. Predicting the effect of toxic substances on pelagic ecosystems. Sci. Total Environ. 44: 111-121.

Borgmann U. 1987. Models on the shape of, and biomass flow up, the biomass size-spectrum. Can. J. Fish. Aquat. Sci. 44(suppl. 2): $136-140$

Borgmann U., Whittle D.M. 1983. Particle-size-conversion efficiency and contaminant concentrations in Lake Ontario biota. Can. J. Fish. Aquat. Sci. 40: 328-336.

Boudreau P.R., Dickie L.M., Kerr S. 1991. Body-size spectra of production and biomass as system-level indicators of ecological dynamics. J. Theor. Biol. 152: 329-339.

Boudreau P.R., Dickie L.M. 1992. Biomass spectra of aquatic ecosystems in relation to fisheries yield. Can. J. Fish. Aquat. Sci. 49: 1528-1538.

Brose U., Berlow E.L., Martinez N.D. 2005. Scaling up keystone effects from simple to complex ecological networks. Ecol. Lett. 8: $1317-1325$

Brose U., Williams R.J., Martinez N.D. 2006. Allometric scaling enhances stability in complex food webs. Ecol. Lett. 9: $1228-1236$.

Brown J.H., Gillooly J.F., Allen A.P., Savage V.M., West G.B. 2004. Toward a metabolic theory of ecology. Ecology 85: 1771-1789.

Brucet S., Boix D., López-Flores R., Badosa A., Moreno-Amich R., Quintana X.D. 2006. Size and species diversity of zooplankton communities in fluctuant Mediterranean salt marshes. Estuar. Coast. Shelf Sci. 67: 424-432.

Camacho J., Sole R.V. 2001. Scaling in ecological size spectra. Europhys. Lett. 55(6): 774-780.

Capitán J.A., Delius G.W. 2010. Scale-invariant model of marine population dynamics. Physical Review E 81: 061901.

Choi J.S., Mazumder A., Hansell R.I.C. 1999. Measuring perturbation in a complicated, thermodynamic world. Ecol. Model. 117: 143-158.

Clauset A., Shalizi C.R., Newman M.E.J. 2009. Power-law distributions in empirical data. SIAM Rev. 51: 661-703.

Cousins S.H. 1985. Ecologists build pyramids again. New Scient. 106: $50-54$.
Cury P., Shannon L., Shin Y. 2003. The functioning of marine ecosystems: a fisheries perspective. In: Sinclair M., Valdimarsson G. (eds), Responsible fisheries in the marine ecosystem. FAO, Rome, pp. 103-123.

Daan N., Gislason H., Pope J.G., Rice J.C. 2005. Changes in the North Sea fish community: evidence of indirect effects of fishing? ICES J. Mar. Sci. 62: 177-188.

de Bruyn A.M.H., Marcogliese D.J., Rasmussen J.B. 2002. Altered body size distributions in a large river fish community enriched by sewage. Can. J. Fish. Aquat. Sci. 59: 818-828.

DeAngelis D.L., Goldstein R.A., O'Neill R.V. 1975. A model for trophic interactions. Ecology 56: 881-892.

Dickie L.M., Kerr S.R., Boudreau P.R. 1987. Size-dependent processes underlying regularities in ecosystem structure. Ecol. Monogr. 57: 233-250.

Dimech, M., Camilleri, M.,Hiddink, J.G., Kaiser M.J., Ragonese S., Schembri P.J. 2008. Differences in demersal community structure and body-size spectra within and outside the Maltese Fishery Management Zone. Sci. Mar. 72(4): 669-682.

Drgas A., Radziejewska T., Warzocha J. 1998. Biomass size Spectra of near-shore shallow-water benthic communities in the Gulf of Gdansk (Southern Baltic Sea). Mar. Ecol. 19(3): 209-228.

Echevarría F., Carrillo P., Jimenez F., Sanchez-Castillo P., CruzPizarro L., Rodriguez J. 1990. The size-abundance distribution and taxonomic composition of plankton in an oligotrophic, high mountain lake (La Caldera, Sierra Nevada, Spain). J. Plankton Res. 12(2): 415-422.

Finlay K., Beisner B.E., Patoine A., Pinel-Alloul B. 2007. Regional ecosystem variability drives the relative importance of bottomup and top-down factors of zooplankton size spectra. Can. J. Fish. Aquat. Sci. 64: 516-529.

Gaedke U. 1993. Ecosystem analysis based on biomass-size distributions: a case study of a plankton community in a large lake. Limnol. Oceanogr. 38: 112-127.

Garcia S.M., Kolding J., Rice J., Rochet M.J., Zhou S., Arimoto T., Beyer J.E., Borges L., Bundy A., Dunn D., Fulton E.A., Hall M., Heino M., Law R., Makino M., Rijnsdorp A.D., Simard F., Smith A.D.M. 2012. Reconsidering the consequences of selective fisheries. Science 335(6072): 1045-1047.

Gislason H., Rice J. 1998. Modelling the response of size and diversity spectra of fish assemblages to changes in exploitation. ICES J. Mar. Sci. 55: 362-370.

Gobert B. 1994. Size structures of demersal catches in a multispecies multigear tropical fishery. Fish. Res. 19:87-104.

Gómez-Canchong P., Quiñones R.A., Brose U. 2013. Robustness of normalized biomass size-structure across ecological networks. Theor. Ecol. 6: 45-56.

Gómez-Canchong P., Quiñones R.A., Manjarrés L.M. 2011. Size structure of a heavily fished benthic/demersal community by shrimp trawling in the Colombian Caribbean Sea. Lat. Am. J. Aquat. Res. 39(1): 43-55.

Jennings S., Dinmore T.A., Duplisea D.E., Warr K.J., Lancaster J.E. 2001. Trawling disturbance can modify benthic production processes. J. Anim. Ecol. 70: 459-475.

Jennings S., Dulvy N.K. 2005. Reference points and reference directions for size-based indicators of community structure. ICES J. Mar. Sci. 62: 397-404.

Jennings S., Kaiser M.J. 1998. The effects of fishing on marine ecosystems. Adv. Mar. Biol. 34: 201-352.

Kerr S.R., Dickie L.M. 2001. Biomass Spectrum. Columbia University Press.

Law R., Plank M.J., James A., Blanchard J.L. 2009. Size spectra dynamics from stochastic predation and growth of individuals. Ecology 90(3): 802-811.

Lundvall D., Svanbäck R., Persson L., Byström P. 1999. Size-dependent predation in piscivores: interactions between predator foraging and prey avoidance abilities. Can. J. Fish. Aquat. Sci. 56: $1285-1292$.

Macpherson E., Gordoa A., García-Rubies A. 2002. Biomass size spectra in littoral fishes in protected and unprotected areas in the NW Mediterranean. Estuar. Coast. Shelf Sci. 55: 777-788.

Macpherson E., Gordoa A. 1996. Biomass spectra in benthic fish assemblages in the Benguela system. Mar. Ecol. Prog. Ser. 138: $27-32$.

Makarieva A.M., Gorshkov V.G., Li B.L. 2004. Body size, energy consumption and allometric scaling: a new dimension in the diversity-stability debate. Ecol. Complex. 1: 139-175. 
Marañón E., Cermeño P., Rodríguez J., Zubkov M.V., Harris R.P. 2007. Scaling of phytoplankton photosynthesis and cell size in the ocean. Limnol. Oceanogr. 52(5): 2120-2198.

McAbendroth L., Ramsay P.M., Foggo A., Rundle S.D., Bilton D.T. 2005. Does macrophyte fractal complexity drive invertebrate diversity, biomass and body size distributions? Oikos 111: 279-290.

MoloneyC.L., Field J.G. 1985. Use of particle-size data to predict potential pelagic-fish yields of some southern African areas. $S$. Afr. J. Mar. Sci. 3: 119-128.

Murawski S.A., Idoine J.S. 1992. Multispecies size composition: A conservative property of exploited fishery systems? J. Northw. Atl. Fish. Sci. 14: 79-85.

Odum E.P. 1971. Fundamentals of Ecology. Third ed. Saunders, Philadelphia.

Pareto V. 1897. Cours d'economie politique. In: Busino G. (ed.) 1964. OEuvres complètes, Busino, vol. 1, Genève.

Pauly D., Christensen V. 1995. Primary production required to sustain global fisheries. Nature (374): 255-257.

Peterson I., Wroblewski J.S. 1984. Mortality rate of fishes in the pelagic ecosystem. Can. J. Fish. Aquat. Sci. 41: 1117-1120.

Platt T. 1985. Structure of the marine ecosystem: Its allometric basis. In: Ulanowicz R.E., Platt T. (eds), Ecosystem theory for biological oceanography. Can. Bull. Fish. Aquat. Sci. 213: 55-64.

Platt T., Denman K. 1977. Organization in the pelagic ecosystem. Helgol. Wiss. Meresunter. 30: 575-581.

Platt T., Denman K. 1978. The structure of the pelagic marine ecosystems. Rapp. Proc.-Verb. Reun. Cons. Perm. Int. Explor. Mer. 173: 60-65.

Pope J.D., Stokes T.K., Murawski S.A., Idoine S.I. 1987. A comparison of fish size composition in the North Sea and on Georges Bank. In: Wolff W., Soeder C.J., Drepper F.R. (eds), Ecodynamics, Contributions to Theoretical Ecology. Springer-Verlag, Berlin, pp. 146-152

Quintana X.D., Comín F.A., Moreno-Amich R. 2002. Biomass-size spectra in aquatic communities in shallow fluctuating Mediterranean salt marshes (Empordà wetlands, NE Spain). J. Plankton Res. 24: 1149-1161.

Quintana X.D., Brucet S., Boix D., López-Flores R., Gascón S., Badosa A., Sala J., Moreno-Amich R., Egozcue J.J. 2008. A nonparametric method for the measurement of size diversity with emphasis on data standarization. Limnol Oceanogr: Meth 6: 75-86.

Quiñones R.A. 1994. A comment on the use of allometry in the study of pelagic ecosystem processes. Sci. Mar. 58: 11-16.

Quiñones R.A., Platt T., Rodríguez J. 2003. Patterns of biomass size spectra from oligotrophic waters of the Northwest Atlantic. Prog. Oceanogr. 57: 405-427.

Quiroga E., Quiñones R.A., Palma M., Sellanes J., Gallardo V.A., Gerdes D., Rowe G. 2005. Biomass size-spectra of macrobenthic communities in the oxygen minimum zone off Chile. Estuar. Coast. Shelf Sci. 62: 217-231.

Real L.A. 1977. Kinetics of functional response. Am. Nat. 111: 289-300.

Rice J., Gislason H. 1996. Patterns of change in the size spectra of numbers and diversity of the North Sea fish assemblage, as reflected in surveys and models. ICES J. Mar. Sci. 53: 1214-1225.

Robson B.J., Barmuta L.A., Fairweather P.G. 2005. Methodological and conceptual issues in the search for a relationship between animal body-size distributions and benthic habitat architecture. Mar. Freshw. Res. 56: 1-11.

Rochet M.J., Benoît E. 2011. Fishing destabilizes the biomass flow in the marine size spectrum. Proc. $R$. Soc. B http://www.ncbi. nlm.nih.gov/pubmed/21632631.

Rodriguez J. 1994. Some comments on the size based structural analysis of the pelagic ecosystem. Sci. Mar. 58: 1-10.

Rodriguez J., Mullin M. 1986. Relation between biomass and body weight of plankton in a steady state oceanic ecosystem. Limnol. Oceanogr. 31(2): 361-370.

San Martin E., Harris R.P., Irigoien X. 2006. Latitudinal variation in plankton size spectra in the Atlantic Ocean. Deep-Sea Res. Part II 53: 1560-1572.

Schwinghamer P. 1985. Observations on size-structure and pelagic coupling of some shelf and abyssal benthic communities. In: Gibbs P.E. (ed.). Proceedings of the 19th European Marine Biology Symposium, September 1984, pp. 347-360.

Sheldon R.W., Prakash A., Sutcliffe Jr W.H. 1972. The size distribution of particles in the ocean. Limnol. Oceanogr. 17: 327-340.

Sheldon R.W., Sutcliffe Jr W.H., Prakash A. 1977. Structure of pelagic food chain and relationships between plankton and fish production. J. Fish. Res. Board Can. 34: 2334-2353.

Shin Y.J., Cury P. 2004. Using an individual-based model of fish assemblages to study the response of size spectra to changes in fishing. Can. J. Fish. Aquat. Sci. 61: 414-431.

Shin Y.J., Rochet M.J., Jennings S., Field J.G., Gislason H. 2005. Using size-based indicators to evaluate the ecosystem effects of fishing. ICES J. Mar.Sci. 62: 384-396.

Silvert W., Platt T. 1978. Energy flux in the pelagic ecosystem: a time dependent equation. Limnol. Oceanogr. 18: 813-816.

Silvert W., Platt T. 1980. Dynamic energy-flow model of the particle size-distribution in pelagic ecosystems. In: Kerfoot W.C. (ed.), Evolution and ecology of zooplankton communities. The University Press of New England, Hanover, New Hampshire, pp. 754-763.

Skalsk, G.T., Gillia, J.F, 2001. Functional responses with predator interference: viable alternatives to the Holling type II model Ecology 82: 3083-3092.

Sprules W.G., Goyke A.P. 1994. Size-Based Strudure and Production in the Pelagia of Lakes Ontario and Michigan. Can. J. Fish. Aquat. Sci. 51: 2603-2611.

Sprules W.G., Munawar M. 1986. Plankton size spectra in relation to ecosystem productivity, size and perturbation. Can. J. Fish. Aquat. Sci. 43: 1789-1794.

Thiebaux M.L., Dickie L.M. 1992. Models of aquatic biomass size spectra and the common structure of their solutions. J. Theor. Biol. 159: 147-161.

Thiebaux M.L., Dickie L.M. 1993. Structure of the body-size spectrum of the biomass in aquatic ecosystems: A consequence of allometry in predator-prey interactions. Can. J. Fish. Aquat. Sci. 50:1308-1317.

Thomann R.V. 1979. An analysis of PCB in Lake Ontario using a size-dependent food chain model. In: Scavia D., Robertson A. (eds), Perspectives on Lake Ecosystem Modelling. Ann. Arbor Sci. 293-320.

Thomann R.V. 1981. Equilibrium model of fate of microcontaminants in diverse aquatic food chains. Can. J. Fish. Aquat. Sci. 38: 280-296.

Vidondo B., Prairie Y., Blanco J.M., Duarte C.M. 1997. Some aspects of the analysis of size spectra in aquatic ecology. Limnol. Oceanogr. 42(1): 184-192.

Wang H., Morrison W., Singh A., Weiss H. 2009. Modeling inverted biomass pyramids and refuges in ecosystems. Ecol. Model. 220: 1376-1382.

Warwick R.M., Collins N.R., Gee J.M., George C.L. 1986. Species size distributions of benthic and pelagic Metazoa: Evidence for interaction. Mar. Ecol. Prog. Ser. 34: 63-68.

White E.P., Ernest S.K.M., Kerkhoff A.J., Enquist B.J. 2007 Relationships between body size and abundance in ecology. Trends Ecol. Evol. 22: 323-330.

Williams R.J. Martinez N.D. 2000. Simple rules yield complex webs. Nature 404: 180-183.

Williams R.J., Martinez N.D. 2004. Stabilization of chaotic and nonpermanent food web dynamics. Eur. Phys. J. B. 38: 297-303.

Yodzis P., Innes S. 1992. Body size and consumer-resource dynamics. Am. Nat. 139: 1151-1175.

Yvon-Durocher G., Montoya J.M., Trimmer M., Woodward G. 2011. Warming alters the size spectrum and shifts the distribution of biomass in freshwater ecosystems. Glob. Chang. Biol. 17: 1681-1694.

Zhou M. 2006. What determines the slope of a plankton biomass spectrum? J. Plankton Res. 28(5): 437-448.

Scient. ed.: F. Peters.

Received August 9, 2012. Accepted February 7, 2013.

Published online March 22, 2013. 